\title{
Elemental Mercury Concentrations and Fluxes in the Tropical Atmosphere and Ocean
}

\section{Citation}

Soerensen, Anne L., Robert P. Mason, Prentiss H. Balcom, Daniel J. Jacob, Yanxu Zhang, Joachim Kuss, and Elsie M. Sunderland. 2014. "Elemental Mercury Concentrations and Fluxes in the Tropical Atmosphere and Ocean." Environ. Sci. Technol. 48 (19) (October 7): 11312-11319. doi:10.1021/es503109p.

\section{Published Version}

doi:10.1021/es503109p

\section{Permanent link}

http://nrs.harvard.edu/urn-3:HUL.InstRepos:34306002

\section{Terms of Use}

This article was downloaded from Harvard University's DASH repository, and is made available under the terms and conditions applicable to Open Access Policy Articles, as set forth at http:// nrs.harvard.edu/urn-3:HUL.InstRepos:dash.current.terms-of-use\#OAP

\section{Share Your Story}

The Harvard community has made this article openly available.

Please share how this access benefits you. Submit a story.

\section{Accessibility}


1 Elemental mercury concentrations and fluxes in the tropical atmosphere and

2 ocean

4 Anne L. Soerensen ${ }^{a, b *}$, Robert P. Mason ${ }^{c}$, Prentiss H Balcomc, Daniel J. Jacob ${ }^{b}$, Yanxu

$5 \quad$ Zhang $^{b}$, Joachim Kuss ${ }^{d}$, Elsie M. Sunderland ${ }^{a, b}$

6

$7{ }^{\mathrm{a}}$ Harvard School of Public Health, Department of Environmental Health, Boston MA, 02215,

8 USA

9 bHarvard University, School of Engineering and Applied Sciences, Cambridge MA, 02138,

10 USA

11 cUniversity of Connecticut, Department of Marine Sciences, 1080 Sennecossett Road,

12 Groton, CT, 0634, USA

13 dDepartment of Marine Chemistry, Leibniz Institute for Baltic Sea Research, Rostock,

14 Germany

15

$16 *$ Corresponding Author

17

18

19 


\section{Abstract}

21 Air-sea exchange of elemental mercury $\left(\mathrm{Hg}^{0}\right)$ is a critical component of the global

22 biogeochemical $\mathrm{Hg}$ cycle. To better understand variability in atmospheric and oceanic $\mathrm{Hg}^{0}$, we

23 collected high-resolution measurements across large gradients in temperature, salinity, and

24 productivity in the Pacific Ocean $\left(20^{\circ} \mathrm{N}-15^{\circ} \mathrm{S}\right)$. Surface seawater $\mathrm{Hg}^{0}$ was much more variable

25 than atmospheric concentrations. Peak seawater $\mathrm{Hg}^{0}(\sim 130 \mathrm{fM})$ observed in the inter-tropical

26 convergence zone (ITCZ) were $\sim 3$-fold greater than surrounding areas $(\sim 50 \mathrm{fM})$, and are

27 comparable to latitudinal gradients in the Atlantic Ocean. Peak evasion in the northern ITCZ was

28 four times higher than surrounding oceanographic regimes and located where high wind speed

29 and elevated seawater $\mathrm{Hg}^{0}$ coincided. A modeling analysis using the MITgcm and atmospheric

30 inputs from the GEOS-Chem global Hg model suggests that higher Hg inputs from enhanced

31 precipitation in the ITCZ combined with the shallow ocean mixed layer in this region can

32 explain observations. Modeled seawater $\mathrm{Hg}^{0}$ concentrations reproduce the observed seawater

$33 \mathrm{Hg}^{0}$ peaks in the ITCZ of the Atlantic and Pacific Oceans but underestimate its magnitude, likely

34 due to insufficient deep convective scavenging of oxidized Hg from the upper troposphere. Our

35 results demonstrate the importance of scavenging of reactive mercury in the upper atmosphere

36 driving variability in seawater $\mathrm{Hg}^{0}$ and net $\mathrm{Hg}$ inputs to biologically productive regions of the

37 tropical ocean. 


\section{Introduction}

42 Air-sea exchange of elemental mercury $\left(\mathrm{Hg}^{0}\right)$ plays a critical role in the global mercury

43 (Hg) cycle by extending the lifetime of anthropogenic $\mathrm{Hg}$ actively cycling in the environment. ${ }^{1,2}$

44 Most human exposure to methylmercury, a neurotoxin, is from pelagic species such as tuna

45 harvested from the open ocean. ${ }^{3,4}$ Reduction of inorganic divalent mercury $\left(\mathrm{Hg}^{\mathrm{II}}\right)$ in seawater to

46 form $\mathrm{Hg}^{0}$ and subsequent evasion to the atmosphere directly reduces the reservoir available for

47 conversion to methylmercury. ${ }^{5}$ Limited observational data on atmospheric and aquatic $\mathrm{Hg}^{0}$ have

48 hampered our ability to model air-sea exchange on a global scale and predict responses to

49 changes in ocean biogeochemistry. ${ }^{6,7}$ Here we report new high-resolution data from the Pacific

50 Ocean on atmospheric and aquatic $\mathrm{Hg}^{0}$ concentrations measured across four oceanographic

51 regimes identified by differences in temperature, salinity and productivity. We use these data to

52 better understand environmental drivers of aqueous $\mathrm{Hg}^{0}$ formation and evasion and discuss

53 improvements to modeling capability motivated by these results and a previous study in the

54 Atlantic.

55 Regional variability in $\mathrm{Hg}^{0}$ evasion mainly reflects differences in turbulent mixing of the

56 surface ocean (wind, bubbles, temperature) and $\mathrm{Hg}^{0}$ concentrations in seawater. ${ }^{8,9}$ Atmospheric

$57 \mathrm{Hg}^{0}$ concentrations in the marine boundary layer are less variable than surface seawater. ${ }^{6}$

58 Atmospheric deposition is the main source of $\mathrm{Hg}$ to the open ocean and plays a large role in

59 determining the pool of $\mathrm{Hg}^{\mathrm{II}}$ available for reduction. ${ }^{8,10}$ The remaining $\sim 40 \%$ of global $\mathrm{Hg}$ inputs

60 to the surface mixed layer of the ocean is from subsurface ocean upwelling, seasonal

61 entrainment, and Ekman pumping. ${ }^{11,12}$

62 Data on variability in $\mathrm{Hg}^{0}$ concentrations in open ocean regions across large gradients in

63 salinity, temperature, productivity, precipitation, and winds are severely limited. Early studies in 
64 the Equatorial Pacific suggested that highest $\mathrm{Hg}^{0}$ concentrations and associated evasion occur in

65 the most productive upwelling regions of the ocean due to enhanced biological reduction, but

66 spatial coverage of measurements was limited. ${ }^{5,13}$ More recent work suggests that photochemical

67 oxidation and reduction of $\mathrm{Hg}$ species occurs much faster than biotic reduction reactions, and

68 elevated ocean productivity may instead decrease seawater $\mathrm{Hg}^{0}$ concentrations through enhanced

69 sorption and scavenging of particle associated $\mathrm{Hg}^{\mathrm{II}}$ that would otherwise be reduced and

70 evaded. ${ }^{6,14,15}$ Along a latitudinal transect of the Atlantic Ocean, Kuss et al. ${ }^{16}$ found a strong

71 tropical maximum in $\mathrm{Hg}^{0}$ concentrations associated with the inter-tropical convergence zone

72 (ITCZ) and significantly lower values in the equatorial upwelling zone, subtropics and mid-

73 latitudes. The authors attributed this spatial variability to a combination of high precipitation,

74 rapid $\mathrm{Hg}^{\mathrm{II}}$ photoreduction due to intense solar radiation, and low wind speeds. Recent modeling

75 efforts have not captured this gradient in $\mathrm{Hg}^{0}$ concentrations between the ITCZ and adjacent

$76 \operatorname{areas}^{11}$ and some suggest elevated concentrations in upwelling regions. ${ }^{12}$

77 Here we analyze new data on $\mathrm{Hg}^{0}$ concentrations measured across four biochemical

78 provinces of the Pacific Ocean, in combination with previously published data from the Atlantic

79 Ocean, to better understand factors driving spatial variability in aqueous $\mathrm{Hg}^{0}$ concentrations. We

80 report high-resolution simultaneous measurements of atmospheric and aquatic $\mathrm{Hg}^{0}$

81 concentrations along a latitudinal transect from $\sim 20^{\circ} \mathrm{N}$ to $\sim 15^{\circ} \mathrm{S}$ in the Pacific Ocean. These

82 measurements capture a large gradient in salinity, temperature, meteorology, productivity, and

83 oceanographic circulation. We use these data in combination with previously collected

84 information from the Atlantic Ocean to better understand factors driving latitudinal patterns in

85 seawater $\mathrm{Hg}^{0}$ concentrations, and discuss implications for improving global air-sea exchange

86 estimates. 


\section{Methods}

89 Field measurements

90 We collected high-resolution measurements of atmospheric and aquatic gaseous $\mathrm{Hg}^{0}$ along

91 the METZYME cruise track in the Pacific Ocean between $1-24$ October 2011 from $20^{\circ} \mathrm{N}$ to $15^{\circ} \mathrm{S}$

92 (Figure 1). We measured atmospheric $\mathrm{Hg}^{0}$ at a 5-minute resolution using a Tekran 2537A

93 mercury vapor analyzer. The instrument was calibrated daily using the internal calibration source

94 and had a detection limit of $<0.2 \mathrm{ng} \mathrm{m}^{-3}$. For aqueous $\mathrm{Hg}^{0}$, we collected seawater from the ship's

95 intake at $7 \mathrm{~m}$ depth and used the automatic continuous equilibrium system with a 5-minute

96 temporal resolution of measurements as described in detail in Andersson et al. ${ }^{17}$ The Tekran

97 2537B used during water sampling was also calibrated daily using the internal calibration source

98 and the detection limit was $<2 \mathrm{fM}$ for seawater $\mathrm{Hg}^{0}$.

99 We aggregated all high-resolution measurements including underway measurements of

100 wind speed, salinity, temperature, precipitation, and in situ fluorescence (a proxy for algal

101 productivity) into one-hour averages for statistical analyses. Averaging over an hour is

102 reasonable as the short-term variability in the measurements was small. Dissolved gaseous $\mathrm{Hg}$ in

103 surface seawater is assumed to be mainly $\mathrm{Hg}^{0}$ because studies have shown that it generally

104 contains $<5 \%$ dimethylmercury. ${ }^{18-20}$

105

106 Modeling

107 Air-sea fluxes for field measurements were calculated using the Nightingale et al. ${ }^{21}$

108 parameterization for instantaneous wind speeds, the Henry's law coefficient for $\mathrm{Hg}^{0}{ }^{22}$ a

109 temperature-corrected Schmidt number for $\mathrm{CO}_{2},{ }^{23}$ and the Wilke-Chang method for estimation of 
110 a temperature and salinity-corrected $\mathrm{Hg}^{0}$ diffusivity ${ }^{24}$. A variety of values have been proposed

111 for the diffusivity of $\mathrm{Hg}^{0}$, as discussed by Kuss et al. ${ }^{25}$ and to demonstrate the impact of variation

112 in this parameter, the air-sea exchange estimate using their diffusivity parameterization is

113 included in the Table $\mathrm{S} 1 .{ }^{26}$ We selected the Nightingale et al. ${ }^{21}$ parameterization because it

114 provides a mid-range estimate of air-sea exchange. ${ }^{27,28}$

115 We compare observations to modeling results from the MIT General Circulation Model

116 (MITgcm) ${ }^{29}$ driven by inputs from the GEOS-Chem model (version v9-01-02) using 2006-2009

117 meteorological data as described in Zhang et al. ${ }^{30}$ and use the model results to look at total $\mathrm{Hg}$

118 inputs and losses in the surface ocean mixed layer. The MITgcm has a horizontal resolution of

$1191^{\circ} \times 1^{\circ}$ and 23 vertical levels ${ }^{31}$ and includes an ecological simulation of carbon and plankton

120 dynamics (the Darwin model).$^{32}$ Physical advection and diffusion of tracers are driven by ocean

121 circulation data from ECCO-GODAE state estimates. ${ }^{33}$ Differences attributable to variability in

122 meteorological years of the observations are expected to be small (for wet deposition average

123 interannual variability between $2006-2011$ was $<5 \%$ for the Pacific $\left(160^{\circ} \mathrm{N}\right.$ transect) and the

124 Atlantic $\left(25^{\circ} \mathrm{W}\right.$ transect)).

125 The MITgcm includes both lateral and vertical transport of $\mathrm{Hg}$ species due to ocean

126 circulation and settling of suspended particles, as described in Zhang et al. ${ }^{29,34}$ The model was

127 run with repeated circulation and external forcing from current day rivers and deposition for 10

128 years. ${ }^{35}$ Rate coefficients for photochemical and biologically driven redox reactions between $\mathrm{Hg}^{0}$

129 and $\mathrm{Hg}^{\mathrm{II}}$, sorption to suspended particles, and parameterization of air-sea exchange estimates are

130 from published and previously evaluated models of $\mathrm{Hg}$ fate in the ocean. ${ }^{11,34}$

\section{Results and Discussion}


134 regimes representing: (1) the North Pacific $\left(14-20^{\circ} \mathrm{N}\right),(2)$ the $\operatorname{ITCZ}\left(5-14^{\circ} \mathrm{N}\right),(3)$ the Equatorial

135 Pacific $\left(5^{\circ} \mathrm{N}-1^{\circ} \mathrm{S}\right)$, and (4) the South Pacific $\left(1-15^{\circ} \mathrm{S}\right)$ (Figure 1, Figure S1). These are specified

136 based on differences in ocean circulation and atmospheric processes, which are reflected in

137 measureable difference in seawater temperature, salinity, and fluorescence ${ }^{36}$ (Figure 2 ; Table

138 1). The regimes are dynamic and the spatial distribution changes with season. In the North

139 Pacific, seawater is cold with characteristically low productivity. Approaching the ITCZ,

140 seawater temperature increases and salinity declines as the result of high precipitation rates. The

141 ITCZ also experiences substantial wind driven Ekman pumping and stratified surface waters.

142 The equatorial region is dominated by the low temperatures of the South Equatorial Current and

143 high productivity due to upwelling nutrients, while the South Pacific has warmer high salinity

144 water with intermediate productivity. ${ }^{37,38}$

146 Latitudinal variability in $\mathrm{Hg}^{0}$

147 Table 1 and Figure 2 show measured atmospheric and aquatic $\mathrm{Hg}^{0}$ concentrations along the

148 cruise track, associated evasion fluxes, and ancillary data. Atmospheric $\mathrm{Hg}^{0}$ concentrations are

149 significantly elevated in the North Pacific $\left(14-20^{\circ} \mathrm{N}\right)$ and ITCZ $\left(5-14^{\circ} \mathrm{N}\right)$ compared to the

150 equatorial $\left(1-5^{\circ} \mathrm{N}\right)$ and South Pacific $\left(1-15^{\circ} \mathrm{S}\right)$ (Tukey-Kramer test, $\left.p<0.001\right)$. Mean

151 concentrations ranged from $1.15 \mathrm{ng} \mathrm{m}^{-3}$ in the South Pacific up to $1.32 \mathrm{ng} \mathrm{m}^{-3}$ in the North

152 Pacific (Table 1). This pattern is consistent with enrichment of atmospheric mercury in the

153 northern hemisphere from anthropogenic sources, as discussed elsewhere. ${ }^{39,40}$

154 Studies conducted prior to the availability of our present analytical capability for high

155 resolution measurements of aquatic and atmospheric $\mathrm{Hg}^{0}$ suggested enhanced $\mathrm{Hg}^{0}$ in equatorial 
156 upwelling regions. ${ }^{13}$ By contrast, we observed relatively low concentrations of atmospheric $\mathrm{Hg}^{0}$

157 (mean $1.18 \mathrm{ng} \mathrm{m}^{-3}$ ) and aquatic $\mathrm{Hg}^{0}$ (mean $53 \mathrm{fM}$ ) in the equatorial region $\left(1-5^{\circ} \mathrm{N}\right.$ ) compared to

158 more northern oceanographic regimes. High Chla and fluorescence in the equatorial region

159 (Table 1) supports the premise that enhanced removal of $\mathrm{Hg}^{\mathrm{II}}$ associated with suspended particles

160 is likely occurring, lowering the $\mathrm{Hg}^{\mathrm{II}}$ pool available for reduction and associated $\mathrm{Hg}^{0}$

161 concentrations.

162 Seawater $\mathrm{Hg}^{0}$ concentrations differ by almost a factor of three compared to $<20 \%$ for

163 atmospheric $\mathrm{Hg}^{0}$. Concentrations were highest in the warm, low salinity waters of the ITCZ

$164(\sim 130 \mathrm{fM})$ and remained low and fairly stable outside this region $(\sim 47-53 \mathrm{fM})$. This variability is

165 much higher than during four cruises over two years in the vicinity of Bermuda where the

166 average concentration varied by less than a factor of two across cruises. ${ }^{6}$ We attribute high

167 concentrations observed in the oceanographic regime characteristic of the ITCZ to a combination

168 of high $\mathrm{Hg}$ inputs through wet deposition and a shallow mixed layer in this region, the latter

169 making elevated inputs more pronounced (Table 1).

170 Previously reported total $\mathrm{Hg}$ concentrations in wet deposition from across the Pacific (14-75

$171 \mathrm{pM}^{40-42}$ ) are $\sim 50$ times higher than seawater concentrations. Seawater $\mathrm{Hg}^{0}$ and salinity were

172 strongly anti-correlated $\left(\mathrm{R}^{2}=0.63\right)$ across the cruise. Precipitation rates in the ITCZ (2.5-3.0 $\mathrm{m} \mathrm{yr}^{-}$

$173^{1}$ ) are much higher than adjacent areas $\left(0.3-1.0 \mathrm{~m} \mathrm{yr}^{-1}\right)$ (Figure S2) ${ }^{43}$ Deep convective

174 precipitation scavenges upper tropospheric air enriched in $\mathrm{Hg}^{\mathrm{II}}$, resulting in high rainwater

175 concentrations. ${ }^{44}$ A study from the Western Pacific region with deep convection reports an

176 average summertime concentration of total $\mathrm{Hg}$ in wet deposition of $\sim 58 \mathrm{pM}^{45}$

177 Seawater $\mathrm{Hg}^{0}$ also varied significantly within the ITCZ (t-test, $p<0.001$ ), increasing south

178 of $8^{\circ} \mathrm{N}$ (shaded areas on Figure 2) due to a combination of higher inputs from precipitation and 
179 significantly lower wind speeds (t-test, $\mathrm{p}<0.001$ ). Satellite data show an average rainfall of 1-3

$180 \mathrm{~mm} \mathrm{~h}^{-1}$ during the cruise in the southern part of the ITCZ and little precipitation in the northern

$181 \operatorname{part}^{46}$ (Figure S2). The presence of a vertical salinity gradient in the mixed layer in the southern

182 ITCZ but not the northern part supports this premise (Figure S3) and indicates that the ITCZ is

183 moving south. Precipitation of $2 \mathrm{~mm} \mathrm{~h}^{-1}$ with $50 \mathrm{pM} \mathrm{Hg}$ concentrations over just one day $(48 \mathrm{~mm}$

$184 \mathrm{~d}^{-1}$ ) would increase seawater $\mathrm{Hg}$ concentration within the upper 10 meters by $\sim 25 \%$, assuming a

185 background concentration of $\sim 1 \mathrm{pM}^{47}$ Sustained precipitation over several days in the southern

186 part of the ITCZ could, therefore, easily explain the observed increase concentrations in the

187 entire mixed layer $(\sim 30 \mathrm{~m})$.

188 Atmospheric $\mathrm{Hg}^{0}$ is elevated in the northern part of the ITCZ temporarily influenced by

189 the North Eastern trade winds, likely due to the highest evasion fluxes of the cruise observed in

190 this region $\left(>8 \mathrm{ng} \mathrm{m}^{-2} \mathrm{~h}^{-1}\right)$. Lower seawater $\mathrm{Hg}^{0}$ is also apparent in the northern ITCZ compared

191 to southern regions but the observed gradient in concentrations is likely attributable to

192 differences in inputs (wet deposition) rather than losses as discussed above. The rapid

193 equilibrium established between $\mathrm{Hg}^{\mathrm{II}}$ and $\mathrm{Hg}^{0}$ in surface waters ${ }^{14}$ means that changes in $\mathrm{Hg}^{0}$

194 concentrations reflect variability in the larger pool of inorganic $\mathrm{Hg}$ species. The relative increase

195 in evasion in the northern ITCZ is thus not large enough to explain the observed north-south

196 ITCZ gradient in seawater $\mathrm{Hg}^{0}$.

197

198 Latitudinal variability in evasion

199 Air-sea exchange in the northern part of the ITCZ (maximum: $8.73 \mathrm{ng} \mathrm{m}^{-2} \mathrm{~h}^{-1}$ ) was more

200 than four-fold greater (mean: $3.24 \pm 2.22 \mathrm{ng} \mathrm{m}^{2} \mathrm{~h}^{-1}$ ) than in the more southerly oceanographic

201 regimes $\left(0.7-0.8 \mathrm{ng} \mathrm{m}^{-2} \mathrm{~h}^{-1}\right)$ and more than two-fold greater than in the North Pacific (Table 1). 
202 These differences are due to a combination of high seawater $\mathrm{Hg}^{0}$ and the North Eastern trade

203 winds temporarily overlapping with the northern part of the ITCZ during our cruise (Figure 2).

204 Wind speeds throughout the cruise were lowest between $8-12^{\circ} \mathrm{S}\left(<3 \mathrm{~m} \mathrm{~s}^{-1}\right)$, fairly stable between

$2058^{\circ} \mathrm{S}-4^{\circ} \mathrm{N}$, dipped below $3 \mathrm{~m} \mathrm{~s}^{-1}$ again in the southern part of the ITCZ and then rapidly increased

206 to $12 \mathrm{~m} \mathrm{~s}^{-1}$ in the northern regions (Figure 2). Although highest overall $\mathrm{Hg}^{0}$ concentrations

207 occurred in the southern part of the ITCZ, highest evasion fluxes are located in the northern

208 region where high wind speeds (associated with southwards movement of the ITCZ) and

209 elevated seawater $\mathrm{Hg}^{0}$ coincide. Low seawater $\mathrm{Hg}^{0}$ concentrations in the North Pacific between

$210 \quad 12-15^{\circ} \mathrm{N}$ resulted in lower evasion despite high wind speeds. These observations reinforce the

211 importance of understanding variability in seawater $\mathrm{Hg}^{0}$ as a control on the magnitude of air-sea

212 exchange, a factor that has been neglected in some broad scale studies. ${ }^{48}$

214 Large scale drivers of $\mathrm{Hg}^{0}$ across ocean basins

215 Similar latitudinal variability in seawater $\mathrm{Hg}^{0}$ is apparent by comparing data from the

216 Pacific Ocean reported here to data from the Atlantic Ocean ${ }^{16}$ (Figure 3). Kuss et al. ${ }^{16}$ also

217 observed elevated $\mathrm{Hg}^{0}$ concentrations in the low salinity, warm waters of the Equatorial Atlantic

218 Ocean across two seasons. Peak seawater $\mathrm{Hg}^{0}$ in the Atlantic Ocean tracked the movement of the

219 ITCZ between sampling periods in November and May (Figure 3). High $\mathrm{Hg}^{0}$ concentrations in

220 the ITCZ in the Atlantic springtime $(\sim 130 \mathrm{fM})$ were similar to those reported here for the Pacific

221 ( 130 fM), while concentrations measured during the Atlantic fall were higher $(\sim 220 \mathrm{fM}) . \mathrm{Hg}^{0}$

222 concentrations in the tropical Atlantic $(15 \mathrm{~S}-15 \mathrm{~N})$ ranged between 35-60 fM and also matched

223 observations reported for the Pacific here $(\sim 50 \mathrm{fM})$. Variability in evasion fluxes was similar for 
224 the Atlantic and Pacific ranging $\sim 4$ fold across regions with highest fluxes where high wind 225 speeds and elevated $\mathrm{Hg}^{0}$ coincide in the tropical and subtropical oceans.

226 Figure 3 compares simulated $\mathrm{Hg}^{0}$ using the MITgcm in surface seawater (0-10 m depth)

227 to observations from all three cruise transects. The model reproduces much of the observed 228 latitudinal variability in aqueous $\mathrm{Hg}^{0}$ but only captures $45-70 \%$ of the amplitude of the peak in

229 the ITCZ. Kuss et al. ${ }^{16}$ suggested that a combination of a shallow mixed layer and high solar 230 radiation could cause the elevated $\mathrm{Hg}^{0}$ concentrations in the ITCZ but these processes are 231 accounted for in our model simulation. ${ }^{11,29}$

232 Concentrations of $\mathrm{Hg}^{0}$ in the surface ocean reflect the overall pool of inorganic $\mathrm{Hg}$ 233 because there is a rapid equilibrium established between $\mathrm{Hg}^{0}$ and $\mathrm{Hg}^{\mathrm{II}}$ in seawater, as discussed

234 above. ${ }^{14}$ Figure 4 shows the relative importance of various input and loss pathways for inorganic $235 \mathrm{Hg}$ in the surface ocean of the cruise regions sampled. Net inputs from atmospheric deposition 236 are the predominant source in the ITCZ across the Atlantic and Pacific regions. A sensitivity 237 simulation shows that modeled seawater $\mathrm{Hg}^{0}$ is almost proportionally affected by changes in 238 atmospheric $\mathrm{Hg}^{\mathrm{II}}$ inputs in the ITCZ (20\% change in deposition resulted in $14-16 \%$ change in $239 \mathrm{Hg}^{0}$ in the ITCZ and 6-16\% elsewhere; Figure S4). Thus, low bias in modeled seawater $\mathrm{Hg}^{0}$ in

240 the ITCZ compared to observations likely reflects insufficient $\mathrm{Hg}$ deposition in the atmospheric

241 simulation (GEOS-Chem) for this region.

242 The GEOS-Chem model reproduces the precipitation rate in the ITCZ fairly well

243 compared to satellite observations ${ }^{46}$ suggesting the model underestimation is related to limited 244 supply of $\mathrm{Hg}^{\mathrm{II}}$ in the atmosphere. Deep convective cloud systems and high precipitation loads 245 distinguish the ITCZ from other parts of the tropical ocean ${ }^{43,49}$ and recent work has shown that 246 cumulonimbus clouds reaching altitudes of $10-14 \mathrm{~km}$ may enhance $\mathrm{Hg}^{\mathrm{II}}$ scavenging compared to 
247 stratiform clouds ( $4 \mathrm{~km})$ for the same precipitation load. ${ }^{50}$ Insufficient deposition in areas of 248 deep convection has also been noted in comparisons of GEOS-Chem simulated deposition to 249 measured $\mathrm{Hg}$ wet deposition from the MDN network data at mid latitudes. ${ }^{30,51}$ In both the mid-

250 latitudes and the tropics this discrepancy could be caused by model underestimation of upper 251 tropospheric $\mathrm{Hg}^{\mathrm{II}}$, which is supported by recent observations, ${ }^{52}$ or insufficient model scavenging

252 of the upper troposphere. As evidence for the latter, Wang et al. ${ }^{53}$ found that GEOS-Chem 253 greatly overestimates upper tropospheric black carbon concentrations in the tropics. Our work

254 suggests the need for additional measurements of wet deposition in tropical areas and improved

255 understanding of atmospheric $\mathrm{Hg}$ dynamics in regions with deep convection to better quantify 256 mercury deposition and resulting seawater concentrations in the tropics. ${ }^{54}$

257 Figure 4 illustrates the importance of lateral seawater flow in the surface ocean for 258 redistributing enhanced atmospheric mercury deposited in the ITCZ region. Ekman pumping is

259 particularly pronounced in the oceanographic regime that reflects the influence of the ITCZ, 260 resulting in strong horizontal outflow of $\mathrm{Hg}$ in the surface ocean to other regions of the tropical

261 ocean. Upwelling in the equatorial region and along the African coast reintroduces $\mathrm{Hg}$ from the

262 subsurface ocean into the surface ocean. ${ }^{55,56}$ In highly productive regions such as the Patagonian

263 Shelf in the Atlantic, losses from particle settling can exceed evasion. These results clearly

264 illustrate the importance of adequately capturing both $\mathrm{Hg}$ redox chemistry and physical transport

265 processes in the atmosphere and ocean to resolve air-sea exchange estimates. Results presented

266 here suggest enhanced atmospheric Hg inputs in the ITCZ are redistributed through lateral ocean

267 transport of surface waters (Figure 4) to biologically productive regions of the tropical ocean.

\section{Supporting Information}


Additional information, including all data for atmospheric and aquatic $\mathrm{Hg}^{0}$ from the

271 Atlantic and Pacific Oceans and associated evasion fluxes are available free of charge via the

272 Internet at http://pubs.acs.org.

273

274 Acknowledgements

275 We acknowledge financial support from the U.S. National Science Foundation, Chemical

276 Oceanography division (NSF OCE-1130549). ALS acknowledges financial support from the

277 Carlsberg Foundation. We thank the captain, science technicians, and crew of the RV Kilo

278 Moana. And Carl Lamborg and Mak Saito (WHOI) for allowing us to participate in their cruise

279 onboard the RV Kilo Moanai. We thank Elizabeth S. Corbitt, Helen Amos, and Johan Schmidt

280 for helpful discussions.

\section{References}

1. Corbitt, E. S.; Jacob, D. J.; Holmes, C. D.; Streets, D. G.; Sunderland, E. M. Global Source-Receptor Relationships for Mercury Deposition under Present-Day and 2050 Emissions Scenarios. Environ. Sci. Technol. 2011, 45, (24), 10477-10484; DOI 10.1021/Es202496y.

2. Amos, H. M.; Jacob, D. J.; Streets, D. G.; Sunderland, E. M. Legacy Impacts of All-Time Anthropogenic Emissions on the Global Mercury Cycle. Biogeochem. Cycles 2013, 27, 1-12; DOI 10.1002/gbc.20040.

3. Sunderland, E. M. Mercury Exposure from Domestic and Imported Estuarine and Marine Fish in the Us Seafood Market. Environmental Health Perspectives 2007, 115, (2), 235-242; DOI 10.1289/Ehp.9377.

4. $\quad$ Mahaffey, K. R.; Sunderland, E. M.; Chan, H. M.; Choi, A. L.; Grandjean, P.; Marien, K.; Oken, E.; Sakamoto, M.; Schoeny, R.; Weihe, P.; Yan, C. H.; Yasutake, A. Balancing the Benefits of N-3 Polyunsaturated Fatty Acids and the Risks of Methylmercury Exposure from Fish Consumption. Nutr. Rev. 2011, 69, (9), 493-508; DOI 10.1111/j.1753-4887.2011.00415.x.

5. Mason, R. P.; Fitzgerald, W. F. The Distribution and Biogeochemical Cycling of Mercury in the Equatorial Pacific-Ocean. Deep-Sea Res., Part I 1993, 40, (9), 18971924.

6. Soerensen, A. L.; Mason, R. P.; Balcom, P. H.; Sunderland, E. M. Drivers of Surface Ocean Mercury Concentrations and Air-Sea Exchange in the West Atlantic Ocean. 

10.1021/ea401354q.

7. Doney, S. C. The Growing Human Footprint on Coastal and Open-Ocean Biogeochemistry. Science 2010, 328, (5985), 1512-1516.

8. Mason, R. P.; Sheu, G. R. Role of the Ocean in the Global Mercury Cycle. Glob. Biogeochem. Cycles 2002, 16, (4).

9. Andersson, M. E.; Sommar, J.; Gardfeldt, K.; Lindqvist, O. Enhanced Concentrations of

10. Sunderland, E. M.; Mason, R. P. Human Impacts on Open Ocean Mercury Concentrations. Glob. Biogeochem. Cycles 2007, 21, (4); Artn Gb4022; DOI 10.1029/2006gb002876.

11. Soerensen, A. L.; Sunderland, E. M.; Holmes, C. D.; Jacob, D. J.; Yantosca, R. M.; Skov, H.; Christensen, J. H.; Strode, S. A.; Mason, R. P. An Improved Global Model for AirSea Exchange of Mercury: High Concentrations over the North Atlantic. Environ. Sci. Technol. 2010, 44, (22), 8574-8580; DOI 10.1021/Es102032g.

12. Strode, S. A.; Jaegle, L.; Selin, N. E.; Jacob, D. J.; Park, R. J.; Yantosca, R. M.; Mason, R. P.; Slemr, F. Air-Sea Exchange in the Global Mercury Cycle. Glob. Biogeochem. Cycles 2007, 21, (1); DOI 10.1029/2006GB002766.

13. Fitzgerald, W. F.; Gill, G. A.; Kim, J. P. An Equatorial Pacific-Ocean Source of Atmospheric Mercury. Science 1984, 224, (4649), 597-599.

14. Qureshi, A.; O'Driscoll, N. J.; MacLeod, M.; Neuhold, Y. M.; Hungerbuhler, K. Photoreactions of Mercury in Surface Ocean Water: Gross Reaction Kinetics and Possible Pathways. Environ. Sci. Technol. 2010, 44, (2), 644-649; DOI 10.1021/es9012728.

15. O'Driscoll, N. J.; Siciliano, S. D.; Lean, D. R. S.; Amyot, M. Gross Photoreduction Kinetics of Mercury in Temperate Freshwater Lakes and Rivers: Application to a General Model of Dgm Dynamics. Environ. Sci. Technol. 2006, 40, (3), 837-843.

16. Kuss, J.; Zülicke, C.; Pohl, C.; Schneider, B. Atlantic Mercury Emission Determined from Continuous Analysis of the Elemental Mercury Sea-Air Concentration Difference within Transects between 50 Degrees N and 50 Degrees S. Glob. Biogeochem. Cycles 2011, 25.

17. Andersson, M. E.; Gardfeldt, K.; Wangberg, I. A Description of an Automatic Continuous Equilibrium System for the Measurement of Dissolved Gaseous Mercury. Anal. Bioanal. Chem. 2008, 391, (6), 2277-2282; DOI 10.1007/s00216-008-2127-4.

18. Whalin, L.; Kim, E.; Mason, R. Factors Influencing the Oxidation, Reduction, Methylation and Demethylation of Mercury Species in Coastal Waters. Marine Chemistry 2007, 107, 278-294.

19. Mason, R.; Rolfhus, K.; Fitzgerald, W. Methylated and Elemental Mercury Cycling in Surface and Deep-Ocean Waters of the North Atlantic. Water Air and Soil Pollution 1995, 80, (1-4), 665-677.

20. Mason, R. P.; Sullivan, K. A. The Distribution and Speciation of Mercury in the South and Equatorial Atlantic. Deep-Sea Res., Part li 1999, 46, (5), 937-956.

21. Nightingale, P. D.; Malin, G.; Law, C. S.; Watson, A. J.; Liss, P. S.; Liddicoat, M. I.; Boutin, J.; Upstill-Goddard, R. C. In Situ Evaluation of Air-Sea Gas Exchange 
Parameterizations Using Novel Conservative and Volatile Tracers. Glob. Biogeochem. Cycles 2000, 14, (1), 373-387.

22. Andersson, M. E.; Gardfeldt, K.; Wangberg, I.; Stromberg, D. Determination of Henry's Law Constant for Elemental Mercury. Chemosphere 2008, 73, (4), 587-592; DOI 10.1016/j.chemosphere.2008.05.067.

23. Poissant, L.; Amyot, M.; Pilote, M.; Lean, D. Mercury Water-Air Exchange over the Upper St. Lawrence River and Lake Ontario. Environ. Sci. Technol. 2000, 34, (15), 3069-3078.

24. Wilke, C. R.; Chang, P. Correlation of Diffusion Coefficients in Dilute Solutions. AIChE J. 1955, 1, (2), 264-270.

25. Kuss, J.; Holzmann, J.; Ludwig, R. An Elemental Mercury Diffusion Coefficient for Natural Waters Determined by Molecular Dynamics Simulation. Environ. Sci. Technol. 2009, 43, (9), 3183-3186.

26. Kuss, J. Water-Air Gas Exchange of Elemental Mercury: An Experimentally Determined Mercury Diffusion Coefficient for Hg0 Water-Air Flux Calculations. Limnology and Oceanography 2014, 59(5), 7.

27. Wanninkhof, R. Relationship between Wind-Speed and Gas-Exchange over the Ocean. J. Geosphys. Res. Oceans 1992, 97, (C5), 7373-7382.

28. Liss, P. S.; Merlivat, L. Air-Sea Exchange Rates: Introduction and Synthesis. In The Role of Air-Sea Exchange in Geochemical Cycling; Buat-Menard, P., Ed. Reidel Publishing Compant: Dodrecht, 1986; pp 113-127.

29. Zhang, Y.; Jacob, D. J.; Amos, H. M.; Dutkiewicz, S.; Sunderland, C. J. Transport and Fate of Riverine Discharged Mercury in the Ocean: Burial in Coasts and Contributions to Open Ocean Concentrations. In prep 2014.

30. Zhang, Y.; Jaegle, L.; van Donkelaar, A.; Martin, R. V.; Holmes, C. D.; Amos, H. M.; Wang, Q.; Talbot, R.; Artz, R.; Brooks, S.; Luke, W.; Holsen, T. M.; Felton, D.; Miller, E. K.; Perry, K. D.; Schmeltz, D.; Steffen, A.; Tordon, R.; Weiss-Penzias, P.; Zsolway, R. Nested-Grid Simulation of Mercury over North America. Atmos. Chem. Phys. 2012, 12, (14), 6095-6111.

31. Marshall, J.; Hill, C.; Perelman, L.; Adcroft, A. Hydrostatic, Quasi-Hydrostatic, and Nonhydrostatic Ocean Modeling. J. Geosphys. Res. Oceans 1997, 102, (C3), 57335752.

32. Dutkiewicz, S.; Follows, M. J.; Bragg, J. G. Modeling the Coupling of Ocean Ecology and Biogeochemistry. Glob. Biogeochem. Cycles 2009, 23.

33. Wunsch, C.; Heimbach, P. Practical Global Oceanic State Estimation. Physica DNonlinear Phenomena 2007, 230, (1-2), 197-208.

34. Zhang, Y.; Jaegle, L.; Thompson, L. Natural Biogeochemical Cycle of Mercury in a Global Three-Dimensional Ocean Tracer Model. Glob. Biogeochem. Cycles 2014, Published online; DOI: 10.1002/2014GB004814.

35. Amos, H. M.; Jacob, D. J.; Kochman, D.; Horowitz, H. M.; Zhang, Y.; Dutkiewicz, S.; Horvat, M.; Corbitt, E. S.; Sunderland, E. M., Global Biogeochemical Implications of Mercury Discharges from Tivers and Sediment Burial. In Environmental Science and Technology, Submitted.

36. Reygondeau, G.; Lonhurst, A.; Martinez, E.; Beaugrand, G.; Antoine, D.; Maury, O. Dynamic Biogeochemical Provinces in the Global Ocean. Glob. Biogeochem. Cycles 2013, 27, (1-13), 1-13; DOI 10.1002/gbc.20089. 
37. Pennington, J. T.; Mahoney, K. L.; Kuwahara, V. S.; Kolber, D. D.; Calienes, R.; Chavez, F. P. Primary Production in the Eastern Tropical Pacific: A Review. Progress in Oceanography 2006, 69, (2-4), 285-317.

38. Pickard, G. L.; Emery, W. J., Descriptive Physical Oceanography. 5th edition ed.; Pergamon Press: 1990.

39. Slemr, F. Trends in Atmospheric Mercury Concentrations over the Atlantic Ocean and at the Wank Summit, and the Resulting Constraints on the Budget of Atmospheric Mercury. In Global and Regional Mercury Cycles: Sources, Fluxes and Mass Balances; Baeyens, W., Ed. Kluwer Academic Publishers: Netherlands, 1996; Vol. 21, pp 33-84.

40. Fitzgerald, W. F. Cycling of Mercury between the Atmosphere and Oceans. In The Role of Air-Sea Exchange in Geochemical Cycling; Buat-Menard, P., Ed. D. Reidel Publishing Company: 1986; Vol. 185, pp 363-408.

41. Mason, R. P.; Fitzgerald, W. F.; Vandal, G. M. The Sources and Composition of Mercury in Pacific-Ocean Rain. Journal of Atmospheric Chemistry 1992, 14, (1-4), 489-500.

42. Laurier, F. J. G.; Mason, R. P.; Whalin, L.; Kato, S. Reactive Gaseous Mercury Formation in the North Pacific Ocean's Marine Boundary Layer: A Potential Role of Halogen Chemistry. Journal of Geophysical Research-Atmospheres 2003, 108, (D17).

43. NASA: Tropical Rainfall Measuring Mission (Trmm) Website: http://pmm.nasa.gov/TRMM/TRMM-based-climatology (Access date: June 2014).

44. Selin, N. E.; Jacob, D. J. Seasonal and Spatial Patterns of Mercury Wet Deposition in the United States: Constraints on the Contribution from North American Anthropogenic Sources. Atmospheric Environment 2008, 42, (21), 5193-5204.

45. Sheu, G. R.; Lin, N. H. Characterizations of Wet Mercury Deposition to a Remote Islet (Pengjiayu) in the Subtropical Northwest Pacific Ocean. Atmospheric Environment 2013, 77, 474-481.

46. RSS (Remote Sensing System): Remss http://www.remss.com/missions/windsat (Access date: November 2013).

47. Sunderland, E. M.; Krabbenhoft, D. P.; Moreau, J. W.; Strode, S. A.; Landing, W. M. Mercury Sources, Distribution, and Bioavailability in the North Pacific Ocean: Insights from Data and Models. Glob. Biogeochem. Cycles 2009, 23; Artn Gb2010; DOI 10.1029/2008gb003425.

48. De Simone, F.; Gencarelli, C. N.; Hedgecock, I. M.; Pirrone, N. Global Atmospheric Cycle of Mercury: A Model Study on the Impact of Oxidation Mechanisms. Environmental Science and Pollution Research 2014, 21, 4110-4123; 10.1007/s11356-013-2451-X.

49. Hong, G.; Heygster, G.; Miao, J. G.; Kunzi, K. Detection of Tropical Deep Convective Clouds from Amsu-B Water Vapor Channels Measurements. Journal of Geophysical Research-Atmospheres 2005, 110, (D5).

50. Nair, U. S.; Wu, Y.; Holmes, C. D.; Ter Schure, A.; Kallos, G.; Walters, J. T. CloudResolving Simulations of Mercury Scavenging and Deposition in Thunderstorms. Atmos. Chem. Phys. 2013, 13, (19), 10143-10157.

51. Holmes, C. D.; Jacob, D. J.; Corbitt, E. S.; Mao, J.; Yang, X.; Talbot, R.; Slemr, F. Global Atmospheric Model for Mercury Including Oxidation by Bromine Atoms. Atmos. 
441 52. Lyman, S. N.; Jaffe, D. A. Formation and Fate of Oxidized Mercury in the Upper

442 Troposphere and Lower Stratosphere. Nature Geoscience 2012, 5, (2), 114-117.

443 53. Wang, Q. Q.; Jacob, D. J.; Spackman, J. R.; Perring, A. E.; Schwarz, J. P.; Moteki, N.;

444 Marais, E. A.; Ge, C.; Wang, J.; Barrett, S. R. H. Global Budget and Radiative Forcing of Black Carbon Aerosol: Constraints from Pole-to-Pole (Hippo) Observations across the Pacific. Journal of Geophysical Research-Atmospheres 2014, 119, (1), 195-206.

54. Yuan, J. A.; Houze, R. A. Global Variability of Mesoscale Convective System Anvil Structure from a-Train Satellite Data. Journal of Climate 2010, 23, (21), 5864-5888.

55. Doi, T.; Tozuka, T.; Yamagata, T. Interannual Variability of the Guinea Dome and Its Possible Link with the Atlantic Meridional Mode. Climate Dynamics 2009, 33, (7-8), 985-998.

56. Huete-Ortega, M.; Calvo-Diaz, A.; Grana, R.; Mourino-Carballido, B.; Maranon, E. Effect of Environmental Forcing on the Biomass, Production and Growth Rate of Size-Fractionated Phytoplankton in the Central Atlantic Ocean. J. Mar. Sys. 2011, 88, (2), 203-213. 
457 Table 1. Summary of observations across oceanographic regimes of the Pacific Ocean.

\begin{tabular}{|c|c|c|c|c|}
\hline & $\begin{array}{c}\text { North Pacific } \\
14-20^{\circ} \mathrm{N}\end{array}$ & $\begin{array}{c}\text { ITCZ } \\
5-14^{\circ} \mathrm{N}\end{array}$ & $\begin{array}{l}\text { Equator } \\
1^{\circ} \mathrm{S}-5^{\circ} \mathrm{N}\end{array}$ & $\begin{array}{c}\text { South Pacific } \\
1-15^{\circ} \mathrm{S}\end{array}$ \\
\hline $\mathrm{Hg}_{\mathrm{atm}}^{0}\left(\mathrm{ng} \mathrm{m}^{-3}\right)$ & $1.32 \pm 0.1^{\star}$ & $1.27 \pm 0.1^{\star}$ & $1.18 \pm 0.1$ & $1.15 \pm 0.1$ \\
\hline $\mathrm{Hg}_{\mathrm{aq}}(\mathrm{fM})$ & $51.3 \pm 4.1^{\star 0}$ & $104.7 \pm 19.9$ & $53.0 \pm 10.3^{\star}$ & $47.0 \pm 13.3^{\circ}$ \\
\hline $\mathrm{Hg}^{0}$ flux $\left(\mathrm{ng} \mathrm{m}^{2} \mathrm{~h}^{-1}\right)$ & $1.4 \pm 0.2$ & $3.2 \pm 2.2$ & $0.7 \pm 0.4^{\star}$ & $0.8 \pm 0.4^{\star}$ \\
\hline Wind Speed $\left(\mathrm{m} \mathrm{s}^{-1}\right)$ & $9.8 \pm 2.5$ & $6.6 \pm 2.9$ & $5.1 \pm 1.2^{\star}$ & $5.6 \pm 1.7^{\star}$ \\
\hline Sea surface temperature $\left({ }^{\circ} \mathrm{C}\right)$ & $26.1 \pm 0.35$ & $28.2 \pm 0.39^{\star}$ & $26.9 \pm 0.70$ & $28.3 \pm 0.51^{\star}$ \\
\hline Salinity (psu) & $35.0 \pm 0.02$ & $34.3 \pm 0.15$ & $35.1 \pm 0.11$ & $35.7 \pm 0.17$ \\
\hline Fluorescence (unitless) ${ }^{\mathrm{A}}$ & $99.7 \pm 2.6$ & $116.3 \pm 23.6$ & $209.3 \pm 50.7$ & $139.3 \pm 42.3$ \\
\hline Chla $\left(\mathrm{mg} \mathrm{m}^{-3}\right)$ & $0.03-0.06$ & $0.06-0.09$ & $0.12-0.27$ & $0.06-0.15$ \\
\hline Mixed layer depth (m) & 50 & 30 & 100 & 150 \\
\hline
\end{tabular}

458 All regions are significantly different from each other using a Tukey-Kramer test for multiple comparisons unless 459 denoted $^{\star}$ or ${ }^{\circ}$.

460 A Fluorescence was measured with a baseline $\sim 95$ and provides a relative indicator of variability in productivity 461 across the cruise track but cannot be compared between cruises because the baseline value is cruise specific.

462

463 


\section{Figure captions}

Figure 1. Oceanographic regimes sampled on the METZYME cruise and measured seawater $\mathrm{Hg}^{\mathrm{O}}$ concentrations.

Figure 2. Latitudinal variability in measured atmospheric and seawater $\mathrm{Hg}^{0}$ concentrations, associated evasion, and environmental properties on the METZYME cruise between 1-24 October, 2011. Oceanographic regimes for October 2011 are shown; shaded areas denote statistically different regions for $\mathrm{Hg}^{0}$ concentrations within the oceanic regime reflecting the ITCZ.

Figure 3. Comparison of modeled (red) and observed (blue) latitudinal gradients in $\mathrm{Hg}^{0}$ along cruise tracks in the Pacific and the Atlantic Oceans. Model results are from the MITgcm within \pm 2 degrees of the cruise track with atmospheric inputs from the GEOS-Chem global Hg model. Data from the Atlantic Ocean are from Kuss et al. ${ }^{16}$

Figure 4. Modeled inputs and losses of $\mathrm{Hg}$ in the ocean mixed layer across the cruise regions Specifications of the budget calculations reported here are provided in the SI. 


\section{TOC-ART}

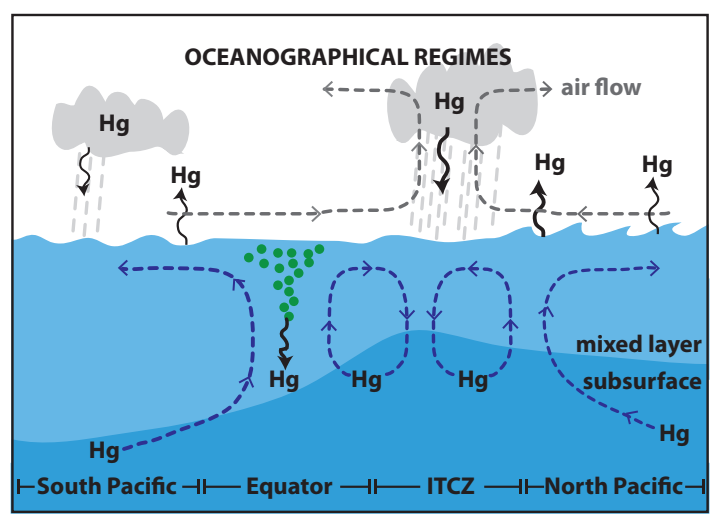

486 


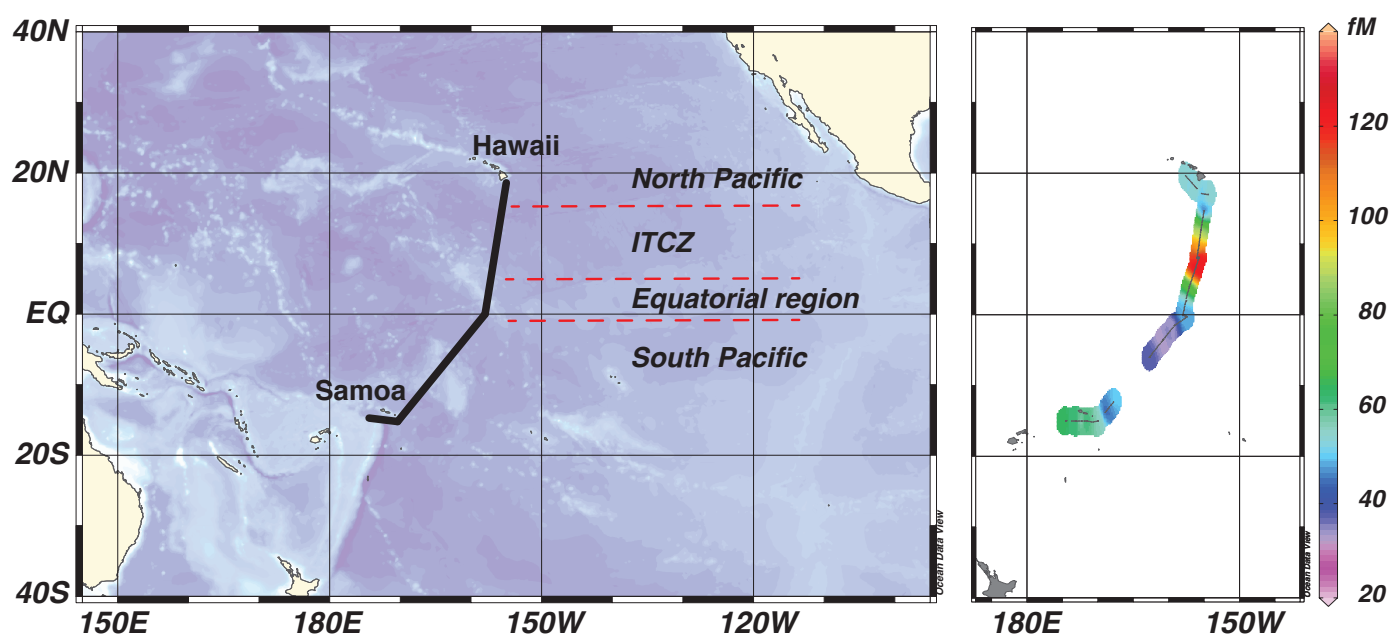

Figure 1. Oceanographic regimes sampled on the METZYME cruise and measured seawater $\mathrm{Hg} 0$ concentrations. 


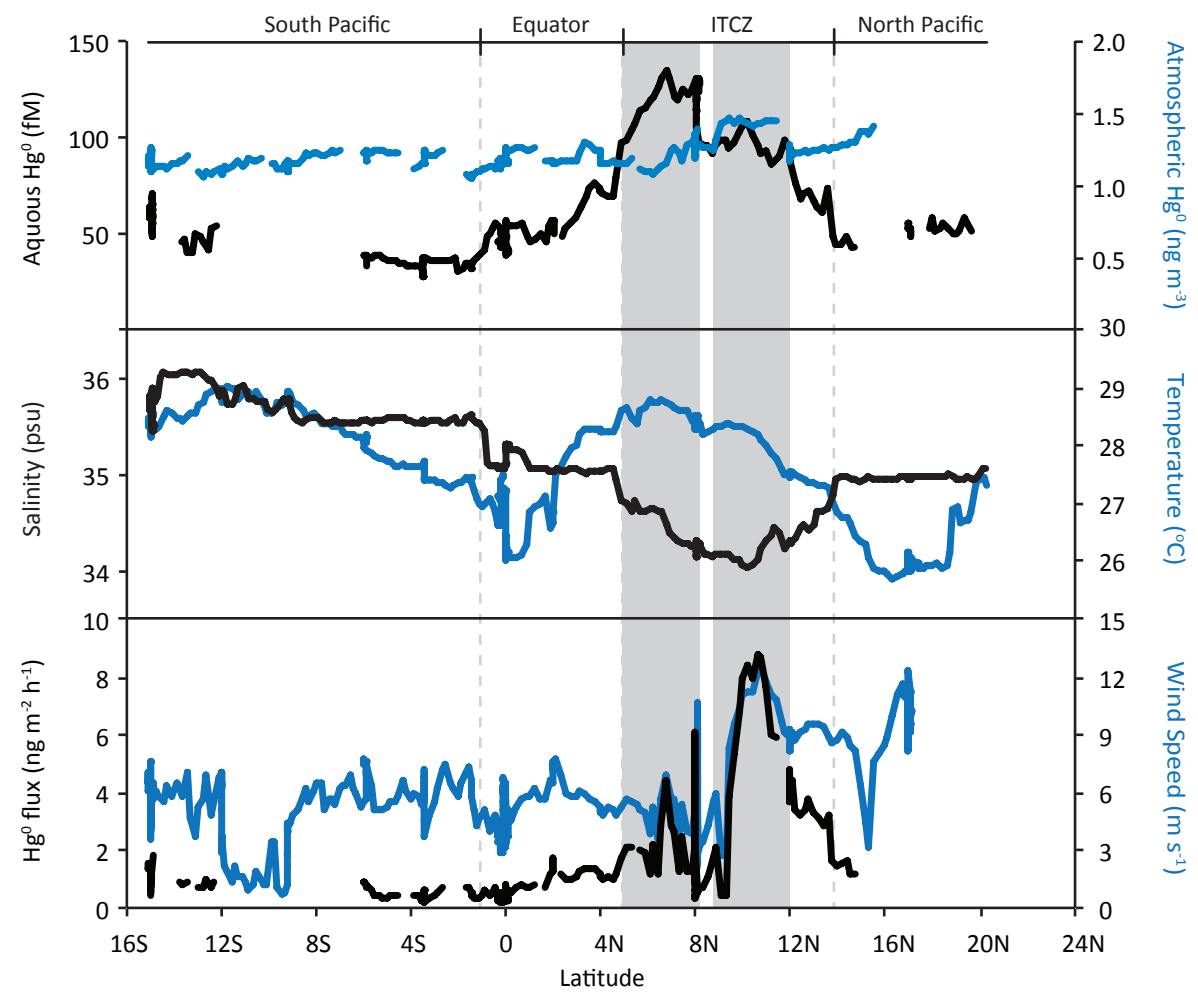

Figure 1. Latitudinal variability in measured atmospheric and seawater $\mathrm{Hg} 0$ concentrations, associated evasion, and environmental properties on the METZYME cruise between 1-24 October, 2011. Oceanographic regimes for October 2011 are shown; shaded areas denote statistically different regions for $\mathrm{Hg} 0$ concentrations within the oceanic regime reflecting the ITCZ. 


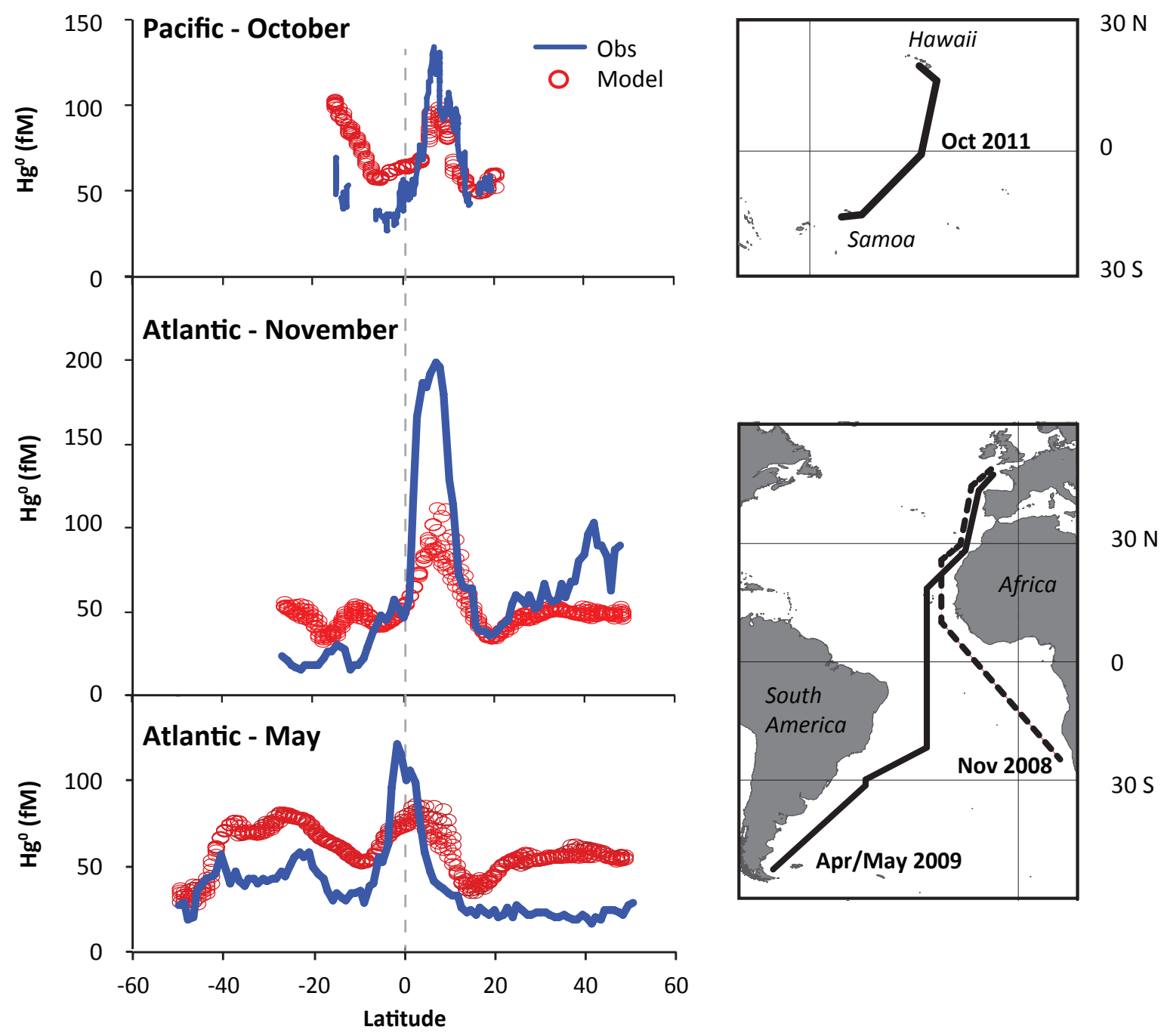

Figure 3. Comparison of modeled (red) and observed (blue) latitudinal gradients in $\mathrm{Hg}^{0}$ along cruise tracks in the Pacific and the Atlantic Oceans. Model results are from the MITgcm within \pm 2 degrees of the cruise track with atmospheric inputs from the GEOS-Chem global Hg model. Data from the Atlantic Ocean are from Kuss et al. ${ }^{16}$ 

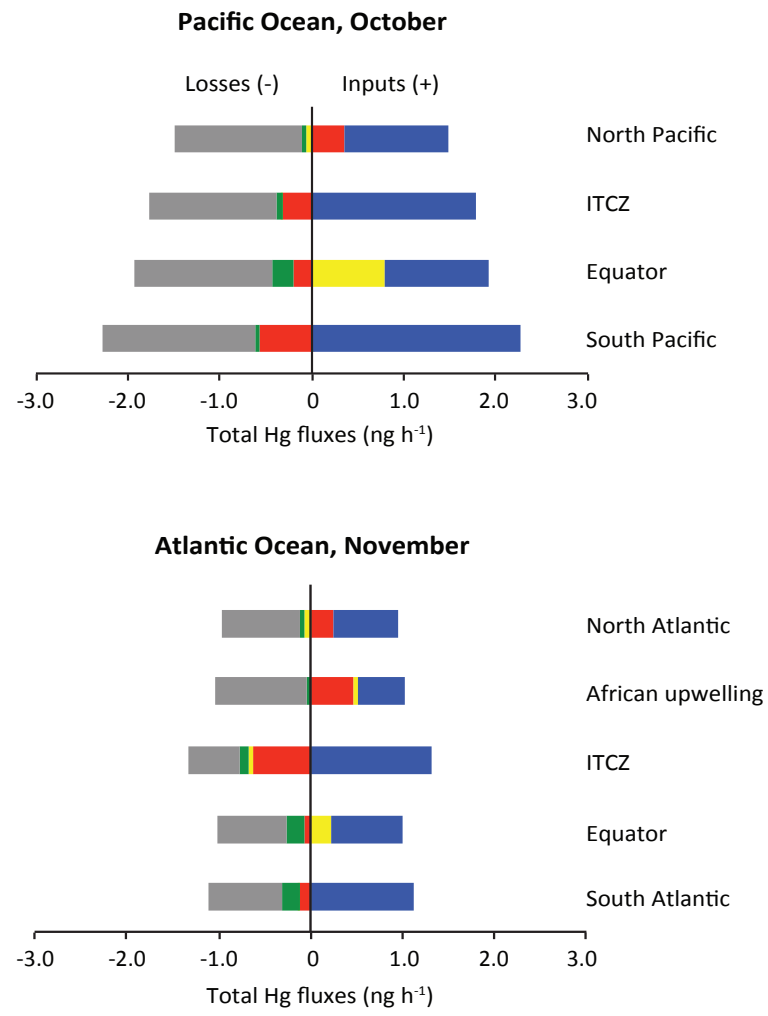

Atlantic Ocean, April/May

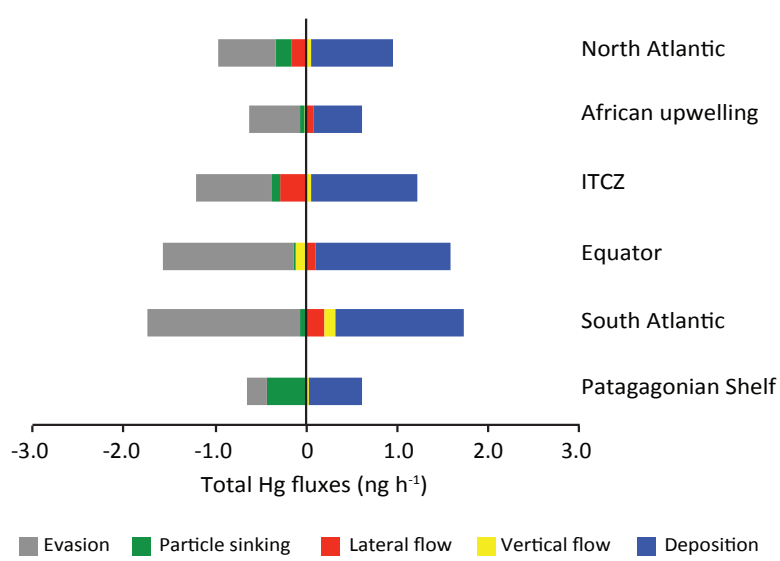

Figure 4. Modeled inputs and losses of $\mathrm{Hg}$ in the ocean mixed layer across the cruise regions sampled. Results are presented as monthly averages from the MITgcm Hg simulation.29 Model comparison with observations indicates a low bias in atmospheric inputs in the ITCZ (Figure 3). Specifications of the budget calculations reported here are provided in 502 the SI. 